\title{
Effects of the Exclusive Enteral Nutrition on the Microbiota Profile of Patients with Crohn's Disease: A Systematic Review
}

\author{
Simona Gatti ${ }^{1, *}$, Tiziana Galeazzi ${ }^{2}$, Elisa Franceschini ${ }^{1}$, Roberta Annibali ${ }^{1}$, Veronica Albano ${ }^{1}$, \\ Anil Kumar Verma ${ }^{2}{ }^{(\mathbb{D})}$, Maria De Angelis ${ }^{3}$, Maria Elena Lionetti ${ }^{1}$ and Carlo Catassi ${ }^{1}$ \\ 1 Department of Pediatrics, Università Politecnica delle Marche, 60123 Ancona, Italy; \\ elisa.franceschini3@gmail.com (E.F.); robertannibali@hotmail.it (R.A.); \\ vero.albano@ospedaliriuniti.marche.it (V.A.); mariaelenalionetti@gmail.com (M.E.L.); \\ c.catassi@univpm.it (C.C.) \\ 2 Laboratory of Metabolic Diseases, Università Politecnica delle Marche, 60123 Ancona, Italy; \\ t.galeazzi@univpm.it (T.G.); anilkrvermaa@gmail.com (A.K.V.) \\ 3 Department of Soil, Plant and Food Sciences, University of Bari A. Moro, 70126 Bari, Italy; \\ maria.deangelis@uniba.it \\ * Correspondence: simona.gatti@hotmail.it; Tel.: +39-071-5962-114
}

Received: 14 April 2017; Accepted: 28 July 2017; Published: 4 August 2017

\begin{abstract}
The mechanisms behind the efficacy of exclusive enteral nutrition (EEN) in Crohn's disease (CD) remain poorly understood, despite the high rate of treatment response. Evidence accumulated in the last 20 years suggests that a positive shift of the disrupted microbiota is one of the treatment effects. The purpose of this study was to critically review and summarize data reporting the microbiological effects of EEN in patients with CD. Fourteen studies were considered in the review, overall involving 216 CD patients on EEN. The studies were heterogeneous in methods of microbiota analysis and exclusion criteria. The most frequently reported effect of EEN was a reduction in microbiota diversity, reversible when patients returned to a normal diet. The effect of EEN on specific bacteria was very variable in the different studies, partially due to methodological limitations of the mentioned studies. The EEN seem to induce some metabolomic changes, which are different in long-term responder patients compared to patients that relapse earlier. Bacterial changes can be relevant to explaining the efficacy of EEN; however, microbiological data obtained from rigorously performed studies and derived from last generation techniques are largely inconsistent.
\end{abstract}

Keywords: microbiota; metabolome; exclusive enteral nutrition; Crohn's disease; IBD; next generation sequencing; 16S rRNA; Faecalibacterium prausntzii

\section{Introduction}

Inflammatory Bowel Disease (IBD), including Crohn's disease (CD), Ulcerative Colitis (UC) and Unclassified IBD (IBD-U), are chronic relapsing inflammatory disorders of the gastrointestinal tract resulting in significant morbidity. Despite the intense research on the underlying mechanisms, the etiology is still unclear. It has been proposed that IBD could be the consequence of an altered balance between the gastrointestinal (GI) microbiota and an inappropriate immune response to the GI bacterial community in subjects with a genetic predisposition [1,2]. The composition, the metabolic functions, and the roles of GI microbiota in IBD have been deeply investigated in the last 20 years, and the results have been recently reviewed and summarized [1,3-5]. Data suggest that bacterial dysbiosis is involved in pathogenesis, recurrence, and complications of IBD (especially increased abundance of Enterobacteriaceae, including adherent invasive Escherichia coli (AIEC) and a decreased abundance of Clostridiales, including Faecalibacterium) [5]. Additionally, changes in the 
microbiota composition (particularly at the mucosal level) potentially have prognostic and therapeutic implications [5]. At diagnosis, there is a window of opportunity to investigate the modifications of microbiota longitudinally, and studies conducted in untreated patients have shown interesting differences in children and adults with IBD [6].

Diet has a prominent role in IBD, and dietary factors have been implicated in the pathogenesis, recurrence, and treatment of IBD $[7,8]$. Exclusive enteral nutrition (EEN) is based on the administration of a liquid formula as the unique source of nutrition for a limited period of time (six to eight weeks). The EEN formulas differ in their protein and fat content and can be classified as elemental (monomeric), semi-elemental (oligomeric), or orpolymeric. Elemental formulas contain individual amino acids and glucose polymers and are generally low in fat. Semi-elemental formulas contain peptides of varying chain length, simple sugars, glucose polymers, or starch and fat, primarily as medium chain triglycerides (MCTs). Polymeric formulas contain intact proteins, complex carbohydrates, and mainly long-chain triglycerides (LCTs). A particular polymeric formula, enriched with an anti-inflammatory molecule (the transforming growth factor-beta 2, TGF- 32 ) has been designed specifically for patients with CD. European guidelines currently recommend EEN as the first-line therapy for inducing remission in pediatric luminal CD [9]. Such recommendations are based on a large amount of data showing rates of EEN-induced clinical remission up to $85 \%$ to $90 \%$, and a rate of mucosal healing in $19 \%$ to $75 \%$ of patients [10-12]. The efficacy of EEN in CD is not correlated to the type of formula used (polymeric versus elemental) [13,14] or to the route of administration (oral versus naso-gastric tube) [15]. The rates of response to EEN are very high if compared to other treatment options in CD, while it is not useful in UC [16]. However, it is still unclear how this treatment works. Anti-inflammatory effects, avoiding specific dietetic components, restoration of the epithelial barrier, and alterations of the intestinal microbiota have been proposed and investigated as possible effects of EEN. The knowledge of these mechanisms can be important to understand the pathogenic events involved in IBD. Studies detailing changes in microbiota composition induced by EEN offer a unique chance to explore the isolated effect of a specific dietetic intervention in the IBD microbiota. Such studies require naïve treatment subjects (at diagnosis) and rigorous methodological criteria (i.e., exclusion subjects on antibiotics and probiotics and using new generation techniques of microbiota analysis).

Based on this background, we aimed to systematically review the existing literature on 'the effects induced by EEN on intestinal microbiota' in order to highlight the current knowledge on this topic, to reveal possible limitations of current studies, and to point out research gaps on this important issue.

\section{The Normal Intestinal Microbiota: Techniques of Analysis}

The human intestinal microbiota is represented by a complex system of bacteria, archaea, viruses, and fungi. In healthy subjects, the bacteria composing the intestinal microbiota primarily belong to two phyla that together represent $90 \%$ of the microbiota; the Firmicutes and the Bacteroidetes. Less represented phyla include Proteobacteria, Actinobacteria (including Bifidobacterium), Fusobacteria, Cyanobacteria, and Verrucomicrobia $[17,18]$. The characterization of the intestinal microbiota was originally based on microbiological techniques, with some limitations in the ability to culture a high proportion of intestinal bacteria [19]. More recently, culture efforts (culturomics) and new techniques in routine bacteriology have increased the number of identified species [20]. The introduction of molecular methods has further expanded the possibility of bacterial identification. More traditional methods, including electrophoresis and real-time quantitative polymerase chain reaction (PCR), are mainly based on the analysis of the $16 \mathrm{~S}$ ribosomal RNA (rRNA) gene. This gene is ubiquitarious in all prokaryotes and contains both highly conserved and species-specific regions. The conserved regions work as amplification targets for PCR primers to extract one or more variable regions of the $16 \mathrm{~S}$ rRNA gene. By using next-generation sequencing (NGS) technologies, the variable regions are replicated, producing thousands of sequenced fragments (reads), which are mapped to known $16 \mathrm{~S}$ rRNA gene sequences of different microbial taxa such as genera or phyla or clustered according to their sequence similarity into "operational taxonomic units" (OTUs) [21]. The shotgun metagenomics 
sequencing approach has been developed in order to avoid some limitations of the more traditional techniques. Here, instead of targeting a specific genomic locus for amplification, all extracted DNA is broken-up into tiny fragments that are independently sequenced. These reads will be in part sampled from taxonomically informative genomic loci (e.g., 16S), while others will be sampled from coding sequences that provide insight into the biological functions encoded in the genome. As a result, metagenomic data provides the opportunity to simultaneously explore both the taxonomical and functional aspects of a microbial community [22].

\section{Materials and Methods}

All studies (including cross-sectional, cohort, case-control, case reports, and series) evaluating the effect induced by the EEN or partial enteral nutrition (PEN) on microbiota composition or metabolomic profile in patients with $\mathrm{CD}$, were considered eligible. Abstracts presented at meetings and articles not published in English were excluded. Studies conducted in children and adults were both considered. No publication date or publication status was imposed. Our search was applied to the Medline database using PubMed by combining key words for Crohn's disease or Inflammatory Bowel Disease AND search terms for Enteral Nutrition, Exclusive Enteral Nutrition, Partial Enteral Nutrition, Exclusive Diet, or Polimeric Diet AND keywords for Microbiota, Microbiome, Metabolome, or Bacterial composition. All studies were published between 1950 (start of Medline) and January 2017. From each study, the following information were extracted: (1) Characteristics of the participants (number, age, disease's status, method of diagnosis, concomitant therapies); (2) Type of microbiota analysis (biological sample and technique of analysis); (3) Nutritional treatment (type of formula, duration of treatment, exclusivity); and (4) Outcome of nutritional treatment and correlations with microbiota changes.

\section{Results}

\subsection{Studies Characteristics}

Fourteen studies were identified (one case-control report and 13 prospective studies, 12 of them including a control group) [23-36]. All the studies were considered relevant for the purpose of this review. The main characteristics and outcomes of the included studies are presented in Table 1.

Two studies were conducted in adults $[25,26]$ and 12 in children $[23,24,27-36]$. Overall 462 subjects were enrolled, 314 of them having CD. Out the 216 enrolled CD subjects that received EEN, longitudinal microbiological data (including at least two consecutive fecal or biopsy samples during an EEN course) were available only for 150 patients. All the studies included subjects with active CD (at diagnosis or during a flare-up). In five studies, the use of antibiotics (in a period of time variable between one week and three months prior to enrollment) was considered an exclusion criteria [23,24,29,30,32]; one study excluded only patients on antibiotic or probiotic treatment during the study period [26]; and another study excluded subjects who had received probiotics in the two weeks before the start of the study [31]. The remaining eight studies did not indicate the use of antibiotics or probiotics as an exclusion criterion. 
Table 1. Characteristics and main outcomes of the 14 studies included in the review.

\begin{tabular}{|c|c|c|c|c|c|c|c|}
\hline Author, Year & Type of Study & $\begin{array}{c}\text { Groups of Subjects } \\
\text { (Number, } \\
\text { Characteristics) }\end{array}$ & $\begin{array}{l}\text { Exclusion Criteria } \\
\text { (ATBs, Probiotics, } \\
\text { Other Drugs) }\end{array}$ & $\begin{array}{l}\text { Biological Sample (Type and } \\
\text { Number of Samples) }\end{array}$ & $\begin{array}{l}\text { Type of Formula } \\
\text { and Duration of } \\
\text { Treatment }\end{array}$ & Microbiota Analysis & Outcomes \\
\hline $\begin{array}{l}\text { Lionetti P et al., } \\
\quad 2005[23]\end{array}$ & $\begin{array}{l}\text { Prospective, } \\
\text { controlled }\end{array}$ & $\begin{array}{c}\text { nine active Crohn's } \\
\text { Disease (CD) } \\
\text { adolescents (nine to } \\
17 \text { years), five controls } \\
\text { (10-15 years) }\end{array}$ & $\begin{array}{l}\text { Antibiotics or } \\
\text { colon cleansing in } \\
\text { the previous week }\end{array}$ & $\begin{array}{l}\text { Fecal samples, multiple samples } \\
\text { during the exclusive enteral } \\
\text { nutrition (EEN) course and } \\
\text { during partial enteral nutrition } \\
\text { (total number not indicated) }\end{array}$ & $\begin{array}{l}\text { Polymeric formula } \\
\text { enriched with } \\
\text { TGF- } \beta 2 \text { for } \\
\text { eight weeks }\end{array}$ & $\begin{array}{l}\text { Temperature gradient gel } \\
\text { electrophoresis (TGGE) } \\
\text { analysis of } 16 \mathrm{~S} \text { rRNA }\end{array}$ & $\begin{array}{l}\text { TGGE profile varied greatly between } \\
\text { subjects and required time to achieve } \\
\text { stability of the band profile in each subject } \\
\text { during exclusive and partial EN } \\
\text { (no statistical analysis available). }\end{array}$ \\
\hline $\begin{array}{l}\text { Leach ST et al., } \\
2008[24]\end{array}$ & $\begin{array}{l}\text { Prospective, } \\
\text { controlled }\end{array}$ & $\begin{array}{l}\text { six } C D \text { children at } \\
\text { diagnosis, mean age } \\
10.2 \text { years }(2.5-13.5) ; \\
\text { seven controls, mean } \\
\text { age } 5.9 \text { years }(2.1-12)\end{array}$ & $\begin{array}{l}\text { Antibiotics or } \\
\text { antiinflammatory } \\
\text { agents in the } \\
\text { previous four } \\
\text { weeks. Severe } \mathrm{CD} \\
\text { requiring surgery } \\
\text { or intensive } \\
\text { medical treatment. }\end{array}$ & $\begin{array}{l}\text { Fecal samples collected prior to } \\
\text { endoscopy and at one, two, four, } \\
\text { six, eight, } 16 \text { and } 26 \text { weeks after } \\
\text { the start of EEN }\end{array}$ & $\begin{array}{l}\text { eight weeks of } \\
\text { EEN (formula } \\
\text { not specified) }\end{array}$ & $\begin{array}{l}\text { PCR amplification of the } \\
\text { bacterial 16S rRNA gene } \\
\text { followed by denaturating gel } \\
\text { electrophoresis (DGGE) }\end{array}$ & $\begin{array}{l}\text { CD children had a greater degree of } \\
\text { change in the bacterial composition during } \\
\text { EEN compared to controls on a normal diet } \\
(p<0.05) \text {. The greatest change was seen in } \\
\text { Ruminococcaceae }(p<0.001) \text { and the least } \\
\text { in the Bacteroides-Prevotella group }(p<0.01) .\end{array}$ \\
\hline $\begin{array}{l}\text { Jia } W \text { et al., } \\
2010[25]\end{array}$ & $\begin{array}{l}\text { Prospective, } \\
\text { controlled }\end{array}$ & $\begin{array}{l}20 \mathrm{CD}, 21 \text { Irritable } \\
\text { bowel syndrome (IBS), } \\
14 \text { Ulcerative colitis } \\
\text { (UC), and } 18 \text { controls }\end{array}$ & Not indicated & $\begin{array}{l}\text { Fecal samples collected before } \\
\text { and after two weeks of } \\
\text { EEN treatment }\end{array}$ & $\begin{array}{l}\text { two weeks of } \\
\text { elemental formula }\end{array}$ & $\begin{array}{l}\text { PCR amplification of } \\
\text { Faecalibacterium prausnitzii } \\
\text { DNA (A2-165 and } \\
\text { M21/2 subgroup) }\end{array}$ & $\begin{array}{l}\text { Levels of } F \text {. prausnitzii A2-165 decreased } \\
\text { significantly }(p=0.0046) \text { after treatment } \\
\text { compared to baseline and to other groups. } \\
\text { Levels of } F \text {. prausnitzii } \mathrm{M} 21 / 2 \text { decreased } \\
\text { without statistical significance }(p=0.61) .\end{array}$ \\
\hline $\begin{array}{l}\text { Shiga H et al., } \\
2012 \text { [26] }\end{array}$ & $\begin{array}{l}\text { Prospective, } \\
\text { controlled }\end{array}$ & $\begin{array}{c}33 \text { active } \mathrm{CD}(\text { median } \\
\text { age: } 30 \text { years, } 15-47), \\
17 \text { controls }\end{array}$ & $\begin{array}{l}\text { No antibiotic or } \\
\text { probiotics during } \\
\text { the study period. }\end{array}$ & $\begin{array}{l}\text { Fecal samples at baseline, after } 38 \\
\text { days for the EEN group, } 35 \text { days } \\
\text { for the total parenteral nutrition } \\
\text { (TPN) group, six weeks for the } \\
\text { controls. In } 12 \text { healthy controls, a } \\
\text { second fecal sample was collected } \\
\text { after six weeks. }\end{array}$ & $\begin{array}{l}\text { eight patients: } \\
\text { eight weeks of } \\
\text { elemental formula; } \\
\text { nine patients on } \\
\text { total parenteral } \\
\text { nutrition }\end{array}$ & $\begin{array}{l}\text { Terminal restriction fragment } \\
\text { length polymorphism } \\
\text { analysis of bacterial } 16 \mathrm{~S} \\
\text { rRNA to evaluate the whole } \\
\text { microbiota. Specific } \\
\text { quantitative PCR to } \\
\text { determine predominant } \\
\text { bacterial groups. }\end{array}$ & $\begin{array}{l}\text { Number of bacterial species was reduced } \\
\text { by EEN in CD ( } p=0.672) \text {, the ratios of } \\
\text { bifidobacteria and Bacteroides fragilis were } \\
\text { reduced ( } p=0.664 \text { and } 0.034 \text {, respectively), } \\
\text { and Enterococcus was increased ( } p=0.788) \text {. }\end{array}$ \\
\hline $\begin{array}{l}\text { Tjellstrom B et al., } \\
2012[27]\end{array}$ & $\begin{array}{l}\text { Prospective } \\
\text { controlled }\end{array}$ & $\begin{array}{c}18 \text { active } C D \text { children, } \\
\text { median age } 13.5 \text { years } \\
(10-17) ; 12 \text { healthy } \\
\text { controls, median age } \\
14.5 \text { years }(14-15.5)\end{array}$ & Not indicated & $\begin{array}{l}\text { Fecal samples (eight patients } \\
\text { collected at the start and finish } \\
\text { of EEN) }\end{array}$ & $\begin{array}{l}\text { six weeks of } \\
\text { polymeric formula }\end{array}$ & $\begin{array}{l}\text { Determination of the fecal } \\
\text { pattern of short-chain-fatty } \\
\text { acids (SCFAs) using } \\
\text { gas-liquid chromatogrphy }\end{array}$ & $\begin{array}{l}\text { Concentration of fecal acetic acid was } \\
\text { reduced by EEN }(p<0.05) \text {, and butyric and } \\
\text { valeric acids were increased }(p=n s) .79 \% \\
\text { of CD showed response to EEN, showing a } \\
\text { fecal pattern of SCFAs similar to } \\
\text { healthy children. }\end{array}$ \\
\hline $\begin{array}{l}\text { D'Argenio et al., } \\
2013[28]\end{array}$ & $\begin{array}{l}\text { Case report, } \\
\text { controlled }\end{array}$ & $\begin{array}{l}\text { one active CD patient } \\
\text { (14 years), one control } \\
\text { with gut polyp } \\
\text { (15 years) }\end{array}$ & Not indicated & Ileum samples & $\begin{array}{l}\text { eight weeks of } \\
\text { polymeric formula }\end{array}$ & $\begin{array}{l}\text { 16S rRNA next-generation } \\
\text { sequencing }\end{array}$ & $\begin{array}{l}\text { Bacterial diversity was reduced in CD } \\
\text { patient at baseline compared to control and } \\
\text { increased after EEN ( } p<0.05) \text {. } \\
\text { Composition changed after therapy } \\
\text { (Bacteroides increased and Proteobacteria } \\
\text { decreased) reaching a distribution similar } \\
\text { to the healthy control (statistical } \\
\text { significance not indicated). }\end{array}$ \\
\hline
\end{tabular}


Table 1. Cont

\begin{tabular}{|c|c|c|c|c|c|c|c|}
\hline Author, Year & Type of Study & $\begin{array}{c}\text { Groups of Subjects } \\
\text { (Number, } \\
\text { Characteristics) }\end{array}$ & $\begin{array}{l}\text { Exclusion Criteria } \\
\text { (ATBs, Probiotics, } \\
\text { Other Drugs) }\end{array}$ & $\begin{array}{l}\text { Biological Sample (Type and } \\
\text { Number of Samples) }\end{array}$ & $\begin{array}{l}\text { Type of Formula } \\
\text { and Duration of } \\
\text { Treatment }\end{array}$ & Microbiota Analysis & Outcomes \\
\hline $\begin{array}{l}\text { Gerasimidis K et al., } \\
2014 \text { [29] }\end{array}$ & $\begin{array}{l}\text { Prospective, } \\
\text { controlled }\end{array}$ & $\begin{array}{c}15 \text { active } C D \text { children } \\
\text { (median age: } 12.7 \text { years), } \\
11 \text { newly diagnosed and } \\
\text { four started a second } \\
\text { EEN course; } \\
21 \text { healthy controls } \\
\text { (median age: } 9.9 \text { years) }\end{array}$ & $\begin{array}{l}\text { Antibiotics in the } \\
\text { previous } 3 \text { months }\end{array}$ & $\begin{array}{l}68 \text { fecal samples from CD subjects } \\
\text { (baseline, } 15 \text { to } 30 \text { days on EEN, } \\
\text { at EEN end, and two to four } \\
\text { months after EEN). } 40 \text { samples } \\
\text { from controls (two samples } \\
\text { for each) }\end{array}$ & $\begin{array}{l}\text { eight weeks of } \\
\text { polymeric formula } \\
\text { TGF- } \beta 2 \text { enriched }\end{array}$ & $\begin{array}{l}\text { 16S rRNA amplification and } \\
\text { quantification with real-time } \\
\text { quantitative PCR. } \\
\text { Measurement of SCFAs by } \\
\text { gas cromatography. } \\
\text { Measurement of D and } \\
\text { L-lactate by enzymatic } \\
\text { commercial assay. } \\
\text { Measurement of fecal sulfide } \\
\text { by a spetrophometric method. }\end{array}$ & $\begin{array}{l}\text { After EEN, the global bacterial diversity } \\
\text { abundance decreased ( } p=0.037) \text { and } \\
\text { returned to normal on a free diet } \\
(p=0.041) \text {. During EEN, concentrations of } \\
\text { F. prausnitzii ( } p=0.002) \text { and Bifidobacterium } \\
\text { genus decreased ( } p=0.053) \text { and } \\
\text { re-increased on a normal diet }(p=0.006 \text { for } \\
\text { Faecalibacterium, } p=\text { ns for } \\
\text { Bacteroides } / \text { Prevotella), but remained } \\
\text { lower compared to healthy subjects. }\end{array}$ \\
\hline $\begin{array}{l}\text { Quince C et al., } \\
2015 \text { [30] }\end{array}$ & $\begin{array}{l}\text { Prospective } \\
\text { controlled }\end{array}$ & $\begin{array}{l}23 \text { active } \mathrm{CD} \text { (age: } \\
6.9-14.7 \text { years) } \\
21 \text { controls (age: } \\
4.6-16.9 \text { years) }\end{array}$ & $\begin{array}{l}\text { Antibiotics in the } \\
\text { previous three } \\
\text { months }\end{array}$ & $\begin{array}{l}78 \text { fecal samples from CD } \\
\text { patients (baseline, during EEN: } \\
\text { 16th to } 32 \text { th and 54th day and } \\
63 \text { days after EEN) } 39 \text { fecal } \\
\text { samples from controls (collected } \\
\text { at least two months apart) }\end{array}$ & $\begin{array}{l}\text { eight weeks of } \\
\text { polymeric formula } \\
\text { TGF- } \beta 2 \text { enriched }\end{array}$ & $\begin{array}{l}\text { Sequencing of } 16 \mathrm{~S} \text { rRNA gene } \\
\text { performed on the MiSeq } \\
\text { platform. Shotgun } \\
\text { metagenome sequencing was } \\
\text { performed for } 69 \text { samples } \\
\text { with the Nextera XT Prep Kit } \\
\text { and the Illumina dual } \\
\text { barcoding Nextera XT Index } \\
\text { kit. Shotgun metagenomics } \\
\text { reads were used also for } \\
\text { assignment to functional } \\
\text { models through alignment to } \\
\text { Kyoto Encyclopedia of Genes } \\
\text { and Genomes (KEGG). }\end{array}$ & $\begin{array}{l}\text { A decrease in species was evident after } \\
15 \text { days of } \operatorname{EEN~}(p=0.037 \text { ). Diversity } \\
\text { returned to baseline when patients were } \\
\text { back to a normal diet but remained lower } \\
\text { (at any time) compared to controls. At the } \\
\text { community level, EEN made the CD } \\
\text { microbial even more dissimilar to that of } \\
\text { healthy controls. 34 genera significantly } \\
\text { were reduced over the EEN course } \\
\text { (including F. prausnitzii); only Lactococcus } \\
\text { increased with EEN. }\end{array}$ \\
\hline $\begin{array}{l}\text { Lewis JD et al., } \\
2015 \text { [31] }\end{array}$ & $\begin{array}{l}\text { Prospective } \\
\text { controlled }\end{array}$ & $\begin{array}{l}90 \text { active CD children } \\
\text { (age: } 10.1-15.5 \text { years): } \\
52 \text { anti-TNF } 21 \text { EEN, } \\
16 \text { PEN } 26 \text { Healthy } \\
\text { controls (age: } \\
\text { 7.9-19.9 years, data } \\
\text { collected from a } \\
\text { previous study) }\end{array}$ & $\begin{array}{l}\text { Probiotics in the } \\
\text { previous two } \\
\text { weeks, children } \\
\text { with an ostomy }\end{array}$ & $\begin{array}{l}366 \text { Fecal samples collected at } \\
\text { baseline, one to four and eight } \\
\text { weeks into therapy }\end{array}$ & $\begin{array}{l}\text { EEN: } 90 \% \text { of } \\
\text { calories from a not } \\
\text { specified dietary } \\
\text { formula; PEN: } \\
53 \% \text { of calories } \\
\text { from formula }\end{array}$ & $\begin{array}{l}\text { Bacterial DNA sequenced } \\
\text { using the Illumina } \\
\text { HiSeq method. }\end{array}$ & $\begin{array}{l}\text { Microbiota composition changed within } \\
\text { one week of EEN, moving farther from the } \\
\text { centroid of healthy controls (overall } \\
p=0.05, \text { among responders } p=0.02, \\
\text { among non responders } p=0.14 \text { ). } \\
\text { Abundance of six genera changed after one } \\
\text { week ( } p=0.05 \text { ). An opposite pattern was } \\
\text { seen in anti-TNF treated patients } \\
\text { (microbiota composition became similar to } \\
\text { healthy controls in one week) and in PEN } \\
\text { treated patients. At the end of the eight } \\
\text { weeks both EEN and anti-TNF responders } \\
\text { had a microbiota composition similar to } \\
\text { healthy controls. }\end{array}$ \\
\hline $\begin{array}{l}\text { Kaakoush NO et al., } \\
2015 \text { [32] }\end{array}$ & $\begin{array}{l}\text { Prospective, } \\
\text { controlled }\end{array}$ & $\begin{array}{l}\text { five newly diagnosed } \\
\text { CD children, five } \\
\text { healthy controls }\end{array}$ & $\begin{array}{l}\text { Antibiotics or } \\
\text { antinflammatory } \\
\text { agents in the } \\
\text { previous } \\
\text { four weeks }\end{array}$ & $\begin{array}{c}39 \text { fecal samples collected at } \\
\text { baseline (at diagnosis, prior to } \\
\text { bowel cleansing for endscopy) } \\
\text { and then at one, two, four, eight, } \\
12,16 \text {, and } 26 \text { weeks } \\
\text { after diagnosis. }\end{array}$ & $\begin{array}{l}\text { eight to } 12 \text { weeks } \\
\text { of a polymeric } \\
\text { formula }\end{array}$ & $\begin{array}{l}\text { 16S rRNA gene and } \\
\text { whole-genome high } \\
\text { throughout sequencing }\end{array}$ & $\begin{array}{l}\text { The number of OTUs decreased during } \\
\text { EEN in responder patients (no statistical } \\
\text { analysis indicated). }\end{array}$ \\
\hline
\end{tabular}


Table 1. Cont.

\begin{tabular}{|c|c|c|c|c|c|c|c|}
\hline Author, Year & Type of Study & $\begin{array}{c}\text { Groups of Subjects } \\
\text { (Number, } \\
\text { Characteristics) }\end{array}$ & $\begin{array}{l}\text { Exclusion Criteria } \\
\text { (ATBs, Probiotics, } \\
\text { Other Drugs) }\end{array}$ & $\begin{array}{l}\text { Biological Sample (Type and } \\
\text { Number of Samples) }\end{array}$ & $\begin{array}{l}\text { Type of Formula } \\
\text { and Duration of } \\
\text { Treatment }\end{array}$ & Microbiota Analysis & Outcomes \\
\hline $\begin{array}{l}\text { Schwerd T et al., } \\
2016 \text { [33] }\end{array}$ & Prospective & $\begin{array}{l}15 \mathrm{CD} \text { children, } \\
12 \text { newly diagnosed } \\
\text { (mean age: } 13.5 \text { years, } \\
\text { SD: } 2.2 \text { years) }\end{array}$ & Not indicated & $\begin{array}{l}24 \text { fecal samples collected from } \\
\text { eight CD subjects at baseline, } \\
\text { week two, and at cessation } \\
\text { of EEN }\end{array}$ & $\begin{array}{l}\text { Polymeric formula } \\
\text { TGF- } \beta 2 \text { enriched } \\
\text { in } 14 \text { patients, } \\
\text { elemental formula } \\
\text { in one patient }\end{array}$ & $\begin{array}{l}\text { High-throughput 16S rRNA } \\
\text { gene sequencing }\end{array}$ & $\begin{array}{l}\text { Altered fecal bacteria composition was } \\
\text { seen after two weeks of EEN (bacterial } \\
\text { profiles clustered from pre-EEN). EEN } \\
\text { decreased the abundance of phylum } \\
\text { Bacteroidetes }(p=0.039) \text { and increased the } \\
\text { abundance of Firmicutes }(p=0.027) \text {. }\end{array}$ \\
\hline $\begin{array}{l}\text { Guinet-Charpentier } \\
\text { C et al., } 2016 \text { [34] }\end{array}$ & $\begin{array}{l}\text { Prospective, } \\
\text { controlled }\end{array}$ & $\begin{array}{l}34 \mathrm{CD} \text { children (median } \\
\text { age } 14.8 \text { years, range } \\
6.5-21) \text { : four children on } \\
\text { EEN, eight on PEN, } \\
22 \text { on other treatments }\end{array}$ & Not indicated & $\begin{array}{c}\text { Fecal samples collected at } \\
\text { baseline, two weeks, and six } \\
\text { weeks after EEN (three patients) }\end{array}$ & $\begin{array}{l}\text { Polymeric formula } \\
\text { TGF- } \beta 2 \text { enriched }\end{array}$ & $\begin{array}{l}\text { MiSeq sequencing of the } 16 \mathrm{~S} \\
\text { rRNA gene }\end{array}$ & $\begin{array}{l}\text { A decrease in genera from the } \\
\text { Proteobacteria phylum (particularly } \\
\text { Sutterella) was observed }(p<0.05) \text {, whereas } \\
\text { Alistipes }(p<0.05) \text { and Bifidobacterium } \\
(p<0.1) \text { increased during EEN. }\end{array}$ \\
\hline $\begin{array}{l}\text { Dunn KA et al., } \\
\quad 2016[35]\end{array}$ & $\begin{array}{l}\text { Prospective, } \\
\text { controlled }\end{array}$ & $\begin{array}{l}10 \text { children with active } \\
\mathrm{CD} \text { (age } 10 \text { to } 16 \text { years) } \\
\text { on EEN for } 12 \text { weeks; } \\
\text { five controls (CD } \\
\text { relatives) on normal diet }\end{array}$ & $\begin{array}{l}\text { Use of other } \\
\text { medications } \\
\text { (including } \\
\text { antibiotics) was } \\
\text { not an } \\
\text { exclusion criteria }\end{array}$ & $\begin{array}{l}19 \text { Fecal samples from CD } \\
\text { patients collected at baseline } \\
\text { (at least } 48 \mathrm{~h} \text { after bowel } \\
\text { preparation) and week } 12\end{array}$ & $\begin{array}{l}12 \text { weeks of EEN } \\
\text { by NG tube }\end{array}$ & $\begin{array}{l}\text { High-throughput sequencing } \\
\text { of the 16S rRNA gene } \\
\text { targeting the V6-V8 region } \\
\text { performed on the Illumina } \\
\text { MiSeq platform }\end{array}$ & $\begin{array}{l}\text { Species diversity (Chao-1 index) decreased } \\
\text { among sustained remission (SR) samples, } \\
\text { whereas it increased among the non-SR } \\
\text { samples over the course. Taxonomic } \\
\text { composition changed over the course of } \\
\text { EEN treatment (no specific statistic } \\
\text { measure is indicated). }\end{array}$ \\
\hline $\begin{array}{l}\text { Dunn KA et al., } \\
2016[36]\end{array}$ & $\begin{array}{l}\text { Prospective, } \\
\text { controlled }\end{array}$ & $\begin{array}{l}15 \mathrm{CD} \text { patients } \\
\text { (aged } 10-16 \text { years), } \\
\text { five controls (age nine to } \\
14 \text { years, relatives of } \\
\text { CD patients) }\end{array}$ & $\begin{array}{l}\text { Use of other } \\
\text { medications } \\
\text { (including } \\
\text { antibiotics) was } \\
\text { not an } \\
\text { exclusion criteria }\end{array}$ & $\begin{array}{l}33 \mathrm{CD} \text { patient samples (15 at } \\
\text { baseline and } 18 \text { at various times } \\
\text { at or after the end of EEN } \\
\text { treatment (week 12). } \\
\text { Five samples from } \\
\text { healthy controls }\end{array}$ & $\begin{array}{l}12 \text { weeks of } \\
\text { polymeric formula }\end{array}$ & $\begin{array}{l}\text { Metagenomic data obtained } \\
\text { by next-generation } \\
\text { sequencing (NGS) (Illumina } \\
\text { MiSeq). Sequences were } \\
\text { compared to } 28 \text { complete } \\
\text { microbial genomes annotated } \\
\text { with KEGG. }\end{array}$ & $\begin{array}{l}\text { Eight KEGG pathways differed } \\
\text { significantly between baseline CD patients } \\
\text { and controls }(p<0.05) \text {. SR patients had } \\
\text { greater similarity to controls than NSR } \\
\text { patients in all cases. }\end{array}$ \\
\hline
\end{tabular}




\subsection{Methodologies of Microbiota Determination}

The earliest study was conducted separating PCR-amplified fragments of $16 S$ rDNA in polyacrylamide gels containing a gradient of denaturating agents (DGGE) or in a temperature gradient (TGGE) [23]. With this method, heteroduplexes of different amplicons (with different G/C contents) were dissociated at different positions in the denaturating or temperature gradient, resulting in a hold of migration. The result was a pattern of bands, which is characteristic of the bacterial community present in the sample. A combination of electrophoresis and real time PCR was used in the studies by Leach et al. and Gerasimidis et al., where bacterial 16S rRNA genes were amplified from stools using primers for different groups of bacteria, allowing specific analysis of each bacteria group [24,29]. Real time quantitative PCR was used in two further studies [25,29]. The most recent studies were performed using next generation sequencing (NGS) techniques [28,30-35]. Microbiota was extracted from fecal samples in all but one single case report, where ileal histological specimens were analyzed instead [28].

\subsection{Overall Effects Induced by EEN on Microbial Composition, Diversity and Abundance}

A significant decrease in the bacterial diversity during EEN treatment was observed in different studies using different techniques. Gerasimidis et al. demonstrated a decrease in the bacterial diversity richness (calculated as the total number of bands on the TTGE images) after 30 days of EEN ( $p=0.041)$, persisting at the end of EEN ( $p=0.037)$ [29]. In the study by Quince et al. diversity in species (represented by the Shannon diversity index) decreased already after two weeks of EEN $(p=0.037)$ [30]. In the same study, at the species level, EEN increased the microbiological distance between CD patients and healthy controls. Lewis et al. reported the same effect from increasing the distance from the healthy subjects microbiota composition with EEN [31]. A reduction in the number of operational taxonomic units (OTUs) was reported also by Kaakoush and collaborators [32]. Quince et al. quantified such reduction, demonstrating a drop of 0.6 points in the Shannon diversity index calculated at the genus level every 10 days of EEN [30]. This corresponds approximately to a reduction in genus diversity of $20 \%$ after one month of EEN. Conversely, in the small study by Schwerd et al., the Shannon diversity index was not affected by the nutritional treatment [33]. The authors attributed this unexpected result to the very stringent parameters used to filter OTUs. Also in the study by Shiga et al., species diversity was not reduced by EEN, in contrast with the effect induced by total parenteral nutrition (TPN) [26]. The reported reduction in microbial diversity seemed to correlate well with the achievement of clinical remission induced by EEN [32] and to reverse when patients returned to a normal diet [29,30,32].

\subsection{Effects on Specific Bacterial Species or Strains}

The effect of the EEN on specific bacteria species varied largely between the different studies. Quince et al. described a statistically significant reduction in 33 genera over the EEN course (including genera that were already less abundant in CD at baseline compared to controls, including Faecalibacteria, Bifidobacteria, and Ruminococcaceae) [30]. In the same report, only Lactococcus increased significantly with EEN ( $p=0.017$ ). A diet-induced reduction in the abundance of Faecalibacterium prausnitzii (belonging to Firmicutes phylum), a bacterium previously considered protective towards the development and flare-up of CD [37,38], was reported both by Jia et al. in adults (a significant decrease was observed for the A2-165 subgroup, $p=0.0046)$ and by Gerasimidis et al. $(p=0.023)$ and Quince et al. (decrease of $-0.0144 \log$ genera abundance, $p=0.068$ ) in CD children $[25,29,30]$. However, in the paper by Kaakoush et al., the authors observed that different OTUs classified under Faecalibacterium responded differently to EEN therapy [32], and, in contrast, Schwerd et al. described an increase in the relative abundance of Firmicutes $(p=0.0227)$, particularly in members of the family Christensenellaceae, with no mention of changes in F. prausnitzii [33]. Among the Bacteroidetes, a significant reduction in the relative sequence abundance of the phylum $(p=0.039)$ was reported by Schwerd et al. [33], and a decrease in Bacteroides fragilis ( $p=0.034)$ was described by Shiga et al. [26]. 
A trend for decreasing concentrations of Bifidobacterium genus, belonging to Actinobacteria phylum (at 60 days of EEN $p=0.120$ ), was reported by Gerasimidis et al., with a subsequent increase when patients were back to a normal free diet $(p=0.031)$ [29]. In the recent report by Guinet-Charpentier et al., a decrease in genera from the Proteobacteria phylum (particularly Sutterella, $p<0.05$ ) was observed, whereas Alistipes $(p<0.05)$ and Bifidobacterium $(p<0.1)$ increased over the course of EEN [34]. Table 2 summarizes specific bacterial changes induced by EEN.

Table 2. Specific bacterial changes induced by exclusive enteral nutrition (EEN).

\begin{tabular}{|c|c|}
\hline Increased during EEN & Decreased during EEN \\
\hline \multicolumn{2}{|c|}{ Firmicutes } \\
\hline Relative abundance of Firmicutes $(p=0.227$ ) [33] & $\begin{array}{l}\text { Levels of A2-165 Faecalibacterium prausnitzii }(p=0.0046) \text { [25] } \\
\text { Levels of M21/2 Faecalibacterium prausnitzii }(p=0.61) \text { [25] } \\
\text { Concentration (log10 16S Ribosomal RNA Gene Copy } \\
\text { Number/g of dry stool) of Faecalibacterium prausnitzii } \\
(p=0.002) \text { [29] }\end{array}$ \\
\hline $\begin{array}{l}\text { Relative abundance of Lactococcus ( } p=0.017) \text { [30] } \\
\text { Relative abundance of Christensenellaceae }(p=0.0237) \text { [33] }\end{array}$ & $\begin{array}{l}\text { Relative abundance of Faecalibacterium }(p=0.068)[30] \\
\text { Relative abundance of Dialister }(p=0.04)[30] \\
\text { Relative abundance of Ruminococcacae }(p=0.04)[30] \\
\text { Relative abundance of Subdoligranulum }(p=0.023)[30]\end{array}$ \\
\hline \multicolumn{2}{|c|}{ Bacteroidetes } \\
\hline Concentration of Bacteroides ( $n=1, p$ not reported) [28] & $\begin{array}{l}\text { Concentration (log } 10 \text { cells per } \mathrm{g} \text { of faeces) of Bacteroides } \\
\text { fragilis }(p=0.034) \text { [26] }\end{array}$ \\
\hline Abundance of Alistipes $(p<0.05)[34]$ & $\begin{array}{l}\text { Concentration of Bacteroides/Prevotella }(p=0.053)[29] \\
\text { Concentration of Prevotella }(p=0.27)[30] \\
\text { Relative abundance of Bacteroidetes }(p=0.039)[33]\end{array}$ \\
\hline \multicolumn{2}{|c|}{ Proteobacteria } \\
\hline & $\begin{array}{l}\text { Concentration of Proteobacteria }(n=1, p \text { not reported) [28] } \\
\text { Concentration of Sutterella }(p<0.05)[34]\end{array}$ \\
\hline \multicolumn{2}{|c|}{ Actinobacteria } \\
\hline \multirow{2}{*}{ Abundance of Bifidobacterium $(p<0.1)[34]$} & Abundance of Bifidobacteriaceae genus $(p=0.005)$ [30] \\
\hline & Concentration of Bifidobacteria $(p=0.003)$ [29] \\
\hline
\end{tabular}

\subsection{EEN Induced Microbiota Changes and Relation to Disease Activity and Remission}

The dietary treatment, in line with the literature, led to a high remission rate in CD subjects (up to $90 \%$ ). The decline in specific bacteria, particularly the levels of $F$. prausnitzii $[25,29]$ and Bacteroides-Prevotella [29], was found to correlate with the achievement of clinical remission. In the recent study by Guinet-Charpentier et al., patients responding to EEN and in clinical remission showed a reduction in Dialister, Blautia, unclassified Ruminococcaceae, and Coprococcus compared with patients in remission with other treatments such as anti-TNF and partial enteral nutrition (the clustering based on microbial distribution was significant with Monte Carlo, $p$ value $=0.029$, based on 10,000 replicates) [34].

In the recent study by Dunn and collaborators, interesting differences emerged between patients that achieved and maintained remission at week 24 after EEN (sustained remission-SR) and patients who did not achieve or maintain remission (non-SR) [35]. Species richness (estimated according to the Chao-1 index) was higher among the SR group (no statistical significance was shown in the text). Over the EEN course, species diversity tended to decrease in the SR group and to increase in the non-SR subjects. Furthermore, the taxonomic composition of the SR group was much more similar to healthy controls at the principle coordinate analysis than the non-SR group (no statistical calculation was made). Akkermansia muciniphila and Bacteroides were particularly prevalent in the SR group, whereas the non-SR group observed a prevalence of Proteobacteria. The authors reported that their 'proposed microbiological model' (based on the microbiota composition of pre-EEN samples) can predict sustained response to EEN with an accuracy of $80 \%$ [35]. The same group also looked at 
differences in the abundance of specific metabolic pathways in SR patients, compared to controls and non-SR patients. The authors initially identified eight metabolic pathways that differed significantly between CD patients and controls ( $p$ value $<0.1$ ); the comparison of these eight pathways showed that SR patients were much more similar to controls compared to non-SR patients in the abundance of these pathways (non-SR patients differed significantly in the abundance of seven of the eight pathways, while SR-patients differed significantly from the controls in the abundance of two pathways only, $p$ value $<0.05$, after correction according to the method of Benjamini and Hochberg). However no significant difference was detected between SR and non-SR samples, possibly due to the small number of samples (10 in total) [36].

Finally, Kaakoush et al. reported re-colonization with specific microbial taxa belonging to six Firmicutes families and that increases in OTUs were correlated with disease recurrence) [32].

\subsection{Effects on Metabolic Pathways}

Short chain fatty acids (SCFAs) are produced in the intestinal lumen by the anaerobic fermentation of non-digestible dietary residues and endogenous epithelial-derived mucus. They are readily absorbed and used as energy sources by colonocytes and also by other tissues [39]. The fecal pool of SCFAs is correlated both to diet and to the microbiota composition and abundance. The three major luminal SCFAs are acetate (acetic acid), propionate (propionic acid), and butyrate (butyric acid). Butyrate is the most extensively studied, and its inflammatory properties are well documented [40]. The anti-inflammatory capacity of acetate is less documented, and interestingly it is also commonly used to induce inflammatory colitis in animal models [41,42], also suggesting pro-inflammatory properties.

Two studies specifically investigated the effects of EEN on the bacterial metabolism. Tjielstrom et al. [27] showed that EEN induced a significant reduction $(p<0.05)$ in the fecal median concentration of the acetic-acid. A parallel increase in anti-inflammatory SCFAs (butyric and valeric acids) was described in the same paper [27], although this change did not reach statistical significance. The same effects were not encountered in children with perianal CD. In the study by Gerasimidis et al., fecal $\mathrm{pH}$ and total sulfide increased, while butyric acid decreased during EEN, and these changes reverted to baseline on a free diet [29]. The metagenomics approach used by Quince et al. revealed that the effect of the EEN was associated with a reduction in the expression of genes involved in biotin and thiamine biosynthesis and a parallel increased expression of genes involved in spermidine/putrescine biosynthesis or in the shikimate pathway [30]. Changes in genes involved in the byosinthesis of vitamin B complex can potentially reflect a decrease in bacteria that express genes encoding these vitamins (e.g., bifidobacteria, Lactobacillus reuteri, and E. coli) or in the production of short or medium chain fatty acids that require these vitamins, or, alternatively, the supplementation of vitamin B complex by EEN may reduce bacterial production. The shikimate pathway is an alternative metabolic route for the biosynthesis of aromatic amino acids (phenylalanine, tyrosine, and tryptophan) employed by microorganisms and plants but not by animals and humans. The biosynthesis and transport of spermidine/putrescine and the shikimate pathway, implicated in the essential aminoacids synthesis, are both fundamental for cell growth and the overexpression of these genes can potentially indicate tissue regeneration [43].

In the recent study by Dunn et al., eight metabolic pathways were initially identified as substantially different in CD patients compared to controls, including pathways involved in xenobiotic and environmental pollutant degradation, succinate metabolism, bacterial HtpG, fatty acid metabolism, and the nucleotide-binding oligomerization domain (NOD)-like receptor signaling pathway. The abundance of pathways implicated in the degradation of environmental pollutants and xenobiotic degradation showed an increase in non-SR patients, whereas pathways involved in NOD-like receptor signaling were reduced in non-SR patients [36]. 


\section{Discussion}

The modification of the intestinal microbiota, commonly reported both in GI and non-GI diseases and widely described in IBD, is one principle potential mechanism behind the efficacy of EEN. In the last 15 years, some studies have tried to elucidate this aspect (which may further contribute to a general comprehension of IBD pathogenesis). Our review aimed to describe the literature on this specific topic, revealing a low number of underpowered and methodologically heterogeneous studies. However, the most recent trials, performed following strict inclusion criteria and using new generation techniques, led to intriguing results.

The origin of the microbial sample is a critical issue in studies describing intestinal bacterial composition. In fact, fecal samples have a big advantage in the low cost and non-invasiveness of the sampling, but the composition of the fecal bacterial population can be extremely different from the mucosal (ileal or colonic) one [6,44,45]. Only the well-detailed case-report by D'Argenio et al. [28] evaluated the intestinal microbiota based on histological samples. However, the importance of the sampling site is minimized by looking at the longitudinal changes induced by the EEN treatment. Both antibiotics and probiotics have been demonstrated to significantly affect the bacterial microbiota community in the GI tract [46,47]. Furthermore, bowel preparation can affect the composition and the diversity of both fecal and luminal microbiota [48]. As previously stated, only six of the considered studies in this review clearly indicated the use of antibiotics as an exclusion criteria, and, in two studies, patients on probiotics were excluded; additionally, bowel preparation was reported only in two studies $[23,35]$. We should consider these methodological pitfalls as possible limitations when extending the results of this review.

Overall, the more recent and well-documented studies seem to indicate a paradoxical effect of EEN on the intestinal microbiota. In fact, a reduction in microbial diversity and/or richness induced by EEN was found in three recent and well-designed studies $[29,30,32]$ that all together examined 43 CD patients on EEN. The diversity at the end of EEN was found to be significantly reduced in comparison with both the microbial diversity of pre-treatment samples and the microbial diversity of healthy controls. This effect reverses following the resumption of a normal diet $[29,30]$. The transitory effect of EEN could explain the reason why this dietetic approach has a very high efficacy as an induction treatment and is able to induce mucosal healing but is less effective in maintenance of remission. These results are in accordance with animal studies [49], demonstrating a decrease in the diversity of bacterial species in interleukin-10 (IL 10) deficient mice fed with an elemental diet compared with mice fed with the regular diet. Interestingly, although limited by the paucity of data and the early techniques, in healthy subjects enteral nutrition also seems to induce a reduction of the total intestinal bacterial count [50]. The same effect has been described in pigs fed with EEN compared to those receiving TPN [51]. Possible explanations are the absence of dietary fiber, with consequent reductions in the exogenous carbohydrate available for fermentation, and/or an increase in intestinal transit time, which may independently reduce microbial mass [52].

The effects of the therapeutic formula on specific bacterial strains were very variable and not consistent between studies. This is not surprising considering both the small sample sizes and the variable methods used in different studies and the huge degree of inter-individual variation in microbiota composition normally encountered in different people. More frequently, studies reported a decrease in the abundance of Firmicutes following a course of EEN [25,29,30], thus increasing the difference of the IBD microbiota subjects from the healthy subjects' bacterial composition. In fact, in patients with IBD, a reduced representation of Firmicutes and a parallel increase in Proteobacteria are generally reported [53-55]. It is plausible, however, that this effect simply reflects a general depletion of all the species already present in the gut at the start of the intervention rather than being a specific effect induced by EEN. In a recent review on the therapeutic utility of EEN in CD, Cuiv and their co-authors suggest that the effect of EEN on intestinal bacteria is mainly based on the limitation of growth and metabolic activity rather than the selection of a specific microbiological pattern [56]. The same authors proposed that the bowel rest induced by EEN may induce mucosal healing by 
limiting the activity of potentially pathogenic microbes and by enhancing repairing mechanisms (autophagy) [56]. The reduction at the end of EEN of F. prausnitzii, a butyrate producing bacteria considered to be protective towards CD development $[37,38]$, reported by some studies $[25,29,30]$ is in agreement with this hypothesis. In fact this reduction could simply be the expression of the general effect induced by EEN. Interestingly, relevant changes in abundance of the AIEC, another bacteria described as potentially pathogenic in IBD [57-59], were not reported in any of the studies. This lack of consistency in pointing out possible community differences might indicate that efforts should be probably directed towards identifying other potentially more relevant discrepancies; for example, at a metabolic or functional level.

\section{Conclusions}

Currently there is limited data on the microbiological effect induced by EEN in subjects with CD. However, the most recent and well-documented results suggest a paradoxic effect of EEN, consisting in a reduction of bacterial diversity and richness. Long-term, multicenter, and rigorous studies based on NGS technology comparing the effect of different treatments are expected to clarify the relevance of microbiological changes induced by the EEN.

Author Contributions: All the authors conceived this work. S.G. performed the literature search and the data extraction and interpreted the data. S.G., C.C., and M.D.A. drafted the manuscript. All the authors revised and approved the final version of the paper.

Conflicts of Interest: The authors declare no conflict of interest.

\section{References}

1. Orel, R.; Kamhi Trop, T. Intestinal microbiota, probiotics and prebiotics in inflammatory bowel disease. World J. Gastroenterol. 2014, 20, 11505-11524. [CrossRef] [PubMed]

2. Serban, D.E. The gut microbiota in the metagenomics era: Sometimes a friend, sometimes a foe. Roum. Arch. Microbiol. Immunol. 2011, 70, 134-140. [PubMed]

3. Hold, G.L.; Smith, M.; Grange, C.; Watt, E.R.; El-Omar, E.M.; Mukhopadhya, I. Role of the gut microbiota in inflammatory bowel disease pathogenesis: What have we learnt in the past 10 years? World J. Gastroenterol. 2014, 20, 1192-1210. [CrossRef] [PubMed]

4. De Cruz, P.; Prideaux, L.; Wagner, J.; Ng, S.C.; McSweeney, C.; Kirkwood, C.; Morrison, M.; Kamm, M.A. Characterization of the gastrointestinal microbiota in health and inflammatory bowel disease. Inflamm. Bowel Dis. 2012, 18, 372-390. [CrossRef] [PubMed]

5. Serban, D.E. Microbiota in Inflammatory Bowel disease pathogenesis and therapy: Is it all about diet? Nutr. Clin. Pract. 2015, 30, 760-779. [CrossRef] [PubMed]

6. Gevers, D.; Kugathasan, S.; Denson, L.A.; Vázquez-Baeza, Y.; Van Treuren, W.; Ren, B.; Schwager, E.; Knights, D.; Song, S.J.; Yassour, M.; et al. The treatment-naive microbiome in new-onset Crohn's disease. Cell Host Microbe 2014, 15, 382-392. [CrossRef] [PubMed]

7. Lee, D.; Albenberg, L.; Compher, C.; Baldassano, R.; Piccoli, D.; Lewis, J.D.; Wu, G.D. Diet in the pathogenesis and treatment of inflammatory bowel diseases. Gastroenterology 2015, 148, 1087-1106. [CrossRef] [PubMed]

8. Penagini, F.; Dilillo, D.; Borsani, B.; Cococcioni, L.; Galli, E.; Bedogni, G.; Zuin, G.; Zuccotti, G.V. Nutrition in Pediatric Inflammatory Bowel Disease: From Etiology to Treatment. A Systematic Review. Nutrients 2016. [CrossRef] [PubMed]

9. Ruemmele, F.M.; Veres, G.; Kolho, K.L.; Griffiths, A.; Levine, A.; Escher, J.C.; Amil Dias, J.; Barabino, A.; Braegger, C.P.; Bronsky, J.; et al. Consensus guidelines of ECCO/ESPGHAN on the medical management of pediatric Crohn's disease. J. Crohns Colitis 2014, 8, 1179-1207. [CrossRef] [PubMed]

10. Grover, Z.; Muir, R.; Lewindon, P. Exclusive enteral nutrition induces early clinical, mucosal and transmural remission in paediatric Crohn's disease. J. Gastroenterol. 2014, 49, 638-645. [CrossRef] [PubMed]

11. Borrelli, O.; Cordischi, L.; Cirulli, M.; Paganelli, M.; Labalestra, V.; Uccini, S.; Russo, P.M.; Cucchiara, S. Polymeric diet alone versus corticosteroids in the treatment of active pediatric Crohn's disease: A randomized controlled open-label trial. Clin. Gastroenterol. Hepatol. 2006, 4, 744-753. [CrossRef] [PubMed] 
12. Berni Canani, R.; Terrin, G.; Borrelli, O.; Romano, M.T.; Manguso, F.; Coruzzo, A.; D’Armiento, F.; Romeo, E.F.; Cucchiara, S. Short- and long-term therapeutic efficacy of nutritional therapy and corticosteroids in paediatric Crohn's disease. Dig. Liver Dis. 2006, 38, 381-387. [CrossRef] [PubMed]

13. Ludvigsson, J.F.; Krantz, M.; Bodin, L.; Stenhammar, L.; Lindquist, B. Elemental versus polymeric enteral nutrition in paediatric Crohn's disease: A multicentre randomized controlled trial. Acta Paediatr. 2004, 93, 327-335. [CrossRef] [PubMed]

14. Verma, S.; Brown, S.; Kirkwood, B.; Giaffer, M.H. Polymeric versus elemental diet as primary treatment in active Crohn's disease: A randomized, double-blind trial. Am. J. Gastroenterol. 2000, 95, 735-739. [CrossRef] [PubMed]

15. Rubio, A.; Pigneur, B.; Garnier-Lengline, H.; Talbotec, C.; Schmitz, J.; Canioni, D.; Goulet, O.; Ruemmele, F.M. The efficacy of exclusive nutritional therapy in paediatric Crohn's disease, comparing fractionated oral vs. continuous enteral feeding. Aliment. Pharmacol. Ther. 2011, 33, 1332-1339. [CrossRef] [PubMed]

16. Ruemmele, F.M.; Pigneur, B.; Garnier-Lengliné, H. Enteral nutrition as treatment option for Crohn's disease: In kids only? Nestlé Nutr. Inst. Workshop Ser. 2014, 79, 115-123. [CrossRef] [PubMed]

17. Human Microbiome Project Consortium. Structure, function and diversity of the healthy human microbiome. Nature 2012, 486, 207-214.

18. Lozupone, C.A.; Stombaugh, J.I.; Gordon, J.I.; Jansson, J.K.; Knight, R. Diversity, stability and resilience of the human gut microbiota. Nature 2012, 489, 220-230. [CrossRef] [PubMed]

19. Shah, R.; Kellermayer, R. Associations of therapeutic enteral nutrition. Nutrients 2014, 21, 5298-5311. [CrossRef] [PubMed]

20. Lagier, J.C.; Hugon, P.; Khelaifia, S.; Fournier, P.E.; La Scola, B.; Raoult, D. The rebirth of culture in microbiology through the example of culturomics to study human gut microbiota. Clin. Microbiol. Rev. 2015, 28, 237-264. [CrossRef] [PubMed]

21. Schmidt, T.S.B.; Matias Rodrigues, J.F.; von Mering, C. Ecological consistency of SSU rRNA-based operational taxonomic units at a global scale. PLoS Comput. Biol. 2014, 10. [CrossRef] [PubMed]

22. Sharpton, T.J. An introduction to the analysis of shotgun metagenomic data. Front. Plant. Sci. 2014. [CrossRef] [PubMed]

23. Lionetti, P.; Callegari, M.L.; Ferrari, S.; Cavicchi, M.C.; Pozzi, E.; de Martino, M.; Morelli, L. Enteral nutrition and microflora in pediatric Crohn's disease. J. Parenter. Enter. Nutr. 2005, 29, S173-S175. [CrossRef] [PubMed]

24. Leach, S.T.; Mitchell, H.M.; Eng, W.R.; Zhang, L.; Day, A.S. Sustained modulation of intestinal bacteria by exclusive enteral nutrition used to treat children with Crohn's disease. Aliment. Pharmacol. Ther. 2008, 28, 724-733. [CrossRef] [PubMed]

25. Jia, W.; Whitehead, R.N.; Griffiths, L.; Dawson, C.; Waring, R.H.; Ramsden, D.B.; Hunter, J.O.; Cole, J.A. Is the abundance of Faecalibacterium prausnitzii relevant to Crohn's disease? FEMS Microbiol. Lett. 2010, 310, 138-144. [CrossRef] [PubMed]

26. Shiga, H.; Kajiura, T.; Shinozaki, J.; Takagi, S.; Kinouchi, Y.; Takahashi, S.; Negoro, K.; Endo, K.; Kakuta, Y.; Suzuki, M.; et al. Changes of faecal microbiota in patients with Crohn's disease treated with an elemental diet and total parenteral nutrition. Dig. Liver. Dis. 2012, 44, 736-742. [CrossRef] [PubMed]

27. Tjellstrom, B.; Hogberg, L.; Stenhammar, L.; Magnusson, K.E.; Midtvedt, T.; Norin, E.; Sundqvist, T. Effect of exclusive enteral nutrition on gut microflora function in children with Crohn's disease. Scand. J. Gastroenterol. 2012, 47, 1454-1459. [CrossRef] [PubMed]

28. D'Argenio, V.; Precone, V.; Casaburi, G.; Miele, E.; Martinelli, M.; Staiano, A.; Salvatore, F.; Sacchetti, L. An altered gut microbiome profile in a child affected by Crohn's disease normalized after nutritional therapy. Am. J. Gastroenterol. 2013, 108, 851-852. [CrossRef] [PubMed]

29. Gerasimidis, K.; Bertz, M.; Hanske, L.; Junick, J.; Biskou, O.; Aguilera, M.; Garrick, V.; Russell, R.K.; Blaut, M.; McGrogan, P.; et al. Decline in presumptively protective gut bacterial species and metabolites are paradoxically associated with disease improvement in pediatric Crohn's disease during enteral nutrition. Inflamm. Bowel. Dis. 2014, 20, 861-871. [CrossRef] [PubMed]

30. Quince, C.; Zeeshan Ijaz, U.; Loman, N.; Eren, A.M.; Saulnier, D.; Russell, J.; Haig, S.J.; Calus, S.T.; Quick, J.; Barclay, A.; et al. Extensive modulation of the fecal metagenome in children with Crohn's disease during Exclusive Enteral Nutrition. Am. J. Gastroenterol. 2015, 110, 1718-1729. [CrossRef] [PubMed] 
31. Lewis, J.D.; Chen, E.Z.; Baldassano, R.N.; Otley, A.R.; Griffiths, A.M.; Lee, D.; Bittinger, K.; Bailey, A.; Friedman, E.S.; Hoffmann, C.; et al. Inflammation, antibiotics, and diet as environmental stressors of the gut microbiome in pediatric Crohn's disease. Cell Host Microbe 2015, 18, 489-500. [CrossRef] [PubMed]

32. Kaakoush, N.O.; Day, A.S.; Leach, S.T.; Lemberg, D.A.; Nielsen, S.; Mitchell, H.M. Effect of exclusive enteral nutrition on the microbiota of children with newly diagnosed Crohn's disease. Clin. Transl. Gastroenterol. 2015, 6, 1-11. [CrossRef] [PubMed]

33. Schwerd, T.; Frivolt, K.; Clavel, T.; Lagkouvardos, I.; Katona, G.; Mayr, D.; Uhlig, H.H.; Haller, D.; Koletzko, S.; Bufler, P. Exclusive enteral nutrition in active pediatric Crohn disease: Effects on intestinal microbiota and immune regulation. J. Allergy Clin. Immunol. 2016, 138, 592-596. [CrossRef] [PubMed]

34. Guinet-Charpentier, C.; Lepage, P.; Morali, A.; Chamaillard, M.; Peyrin-Biroulet, L. Effects of enteral polymeric diet on gut microbiota in children with Crohn's disease. Gut 2017, 66, 194-195. [CrossRef] [PubMed]

35. Dunn, K.A.; Moore-Connors, J.; MacIntyre, B.; Stadnyk, A.; Thomas, N.A.; Noble, A.; Mahdi, G.; Rashid, M.; Otley, A.R.; Bielawski, J.P.; et al. The gut microbiome of pediatric Crohn's disease patients differs from healthy controls in genes that can influence the balance between a healthy and dysregulated immune response. Inflamm. Bowel Dis. 2016, 22, 2607-2618. [CrossRef] [PubMed]

36. Dunn, K.A.; Moore-Connors, J.; MacIntyre, B.; Stadnyk, A.W.; Thomas, N.A.; Noble, A.; Mahdi, G.; Rashid, M.; Otley, A.R.; Bielawski, J.P.; et al. Early changes in microbial community structure are associated with sustained remission after nutritional treatment of pediatric Crohn's disease. Inflamm. Bowel Dis. 2016, 22, 2853-2862. [CrossRef] [PubMed]

37. Sokol, H.; Pigneur, B.; Watterlot, L.; Lakhdari, O.; Bermúdez-Humarán, L.G.; Gratadoux, J.J.; Blugeon, S.; Bridonneau, C.; Furet, J.P.; Corthier, G.; et al. Faecalibacterium prausnitzii is an anti-inflammatory commensal bacterium identified by gut microbiota analysis of Crohn disease patients. Proc. Natl. Acad. Sci. USA 2008, 105, 16731-16736. [CrossRef] [PubMed]

38. Sokol, H.; Seksik, P.; Furet, J.P.; Firmesse, O.; Nion-Larmurier, I.; Beaugerie, L.; Cosnes, J.; Corthier, G.; Marteau, P.; Doré, J. Low counts of Faecalibacterium prausnitzii in colitis microbiota. Inflamm. Bowel Dis. 2009, 15, 1183-1189. [CrossRef] [PubMed]

39. McNeil, N.I. The contribution of the large intestine to energy supplies in man. Am. J. Clin. Nutr. 1984, 39, 338-342. [PubMed]

40. Vinolo, M.A.R.; Rodrigues, H.G.; Nachbar, R.T.; Curi, R. Regulation of Inflammation by Short Chain Fatty Acids. Nutrients 2011, 3, 858-876. [CrossRef] [PubMed]

41. Elson, C.O.; Sartor, R.B.; Tennyson, G.S.; Riddell, R.H. Experimental models of Inflammatory bowel disease. Gastroenterology 1995, 109, 1344-1367. [CrossRef]

42. Fabia, R.; Willén, R.; Ar'Rajab, A.; Andersson, R.; Ahrén, B.; Bengmark, S. Acetic acid-induced colitis in the rat: A reproducible experimental model for acute ulcerative colitis. Eur. Surg. Res. 1992, 24, 211-225. [CrossRef] [PubMed]

43. Slezak, K.; Hanske, L.; Loh, G.; Blaut, M. Increased bacterial putrescine has no impact on gut morphology and physiology in gnotobiotic adolescent mice. Benef. Microbes 2013, 4, 253-266. [CrossRef] [PubMed]

44. Stearns, J.C.; Lynch, M.D.; Senadheera, D.B.; Tenenbaum, H.C.; Goldberg, M.B.; Cvitkovitch, D.G.; Croitoru, K.; Moreno-Hagelsieb, G.; Neufeld, J.D. Bacterial biogeography of the human digestive tract. Sci. Rep. 2011. [CrossRef] [PubMed]

45. Lavelle, A.; Lennon, G.; O'Sullivan, O.; Docherty, N.; Balfe, A.; Maguire, A.; Mulcahy, H.E.; Doherty, G.; O'Donoghue, D.; Hyland, J.; et al. Spatial variation of the colonic microbiota in patients with ulcerative colitis and control volunteers. Gut 2015, 64, 1553-1561. [CrossRef] [PubMed]

46. Dethlefsen, L.; Relman, D.A. Incomplete recovery and individualized responses of the human distal gut microbiota to repeated antibiotic perturbation. Proc. Natl. Acad. Sci. USA 2011, 108, 4554-4561. [CrossRef] [PubMed]

47. Yang, B.; Xiao, L.; Liu, S.; Liu, X.; Luo, Y.; Ji, Q.; Yang, P.; Liu, Z. Exploration of the effect of probiotics supplementation on intestinal microbiota of food allergic mice. Am. J. Transl. Res. 2017, 9, 376-385. [PubMed]

48. Shobar, R.M.; Velineni, S.; Keshavarzian, A.; Swanson, G.; DeMeo, M.T.; Melson, J.E.; Losurdo, J.; Engen, P.A.; Sun, Y.; Koenig, L.; Mutlu, E.A. The Effects of Bowel Preparation on Microbiota-Related Metrics Differ in Health and in Inflammatory Bowel Disease and for the Mucosal and Luminal Microbiota Compartments. Clin. Transl. Gastroenterol. 2016, 7, e143. [CrossRef] [PubMed] 
49. Kajiura, T.; Takeda, T.; Sakata, S.; Sakamoto, M.; Hashimoto, M.; Suzuki, H.; Suzuki, M.; Benno, Y. Change of intestinal microbiota with elemental diet and its impact on therapeutic effects in a murine model of chronic colitis. Dig. Dis. Sci. 2009, 54, 1892-1900. [CrossRef] [PubMed]

50. Whelan, K.; Judd, P.A.; Preedy, V.R.; Simmering, R.; Jann, A.; Taylor, M.A. Fructooligosaccharides and fiber partially prevent the alterations in fecal microbiota and short-chain fatty acid concentrations caused by standard enteral formula in healthy humans. J. Nutr. 2005, 135, 1896-1902. [PubMed]

51. Harvey, R.B.; Andrews, K.; Droleskey, R.E.; Kansagra, K.V.; Stoll, B.; Burrin, D.G.; Sheffield, C.L.; Anderson, R.C.; Nisbet, D.J. Qualitative and quantitative comparison of gut bacterial colonization in enterally and parenterally fed neonatal pigs. Curr. Issues Intest. Microbiol. 2006, 7, 61-64. [PubMed]

52. Stephen, A.M.; Wiggins, H.S.; Cummings, J.H. Effect of changing transit time on colonic microbial metabolism in man. Gut 1987, 28, 601-609. [CrossRef] [PubMed]

53. Nagalingam, N.A.; Lynch, S.V. Role of the microbiota in inflammatory bowel diseases. Inflamm. Bowel Dis. 2012, 18, 968-984. [CrossRef] [PubMed]

54. Frank, D.N.; Robertson, C.E.; Hamm, C.M.; Kpadeh, Z.; Zhang, T.; Chen, H.; Zhu, W.; Sartor, R.B.; Boedeker, E.C.; Harpaz, N.; et al. Disease phenotype and genotype are associated with shifts in intestinal-associated microbiota in inflammatory bowel diseases. Inflamm. Bowel Dis. 2011, 17, 179-184. [CrossRef] [PubMed]

55. Sartor, R.B. The intestinal microbiota in inflammatory bowel diseases. Nestle Nutr. Inst. Workshop Ser. 2014, 79, 29-39. [CrossRef] [PubMed]

56. Cuív, P.Ó.; Begun, J.; Keely, S.; Lewindon, P.J.; Morrison, M. Towards an integrated understanding of the therapeutic utility of exclusive enteral nutrition in the treatment of Crohn's disease. Food Funct. 2016, 7, 1741-1751. [CrossRef] [PubMed]

57. Sasaki, M.; Sitaraman, S.V.; Babbin, B.A.; Gerner-Smidt, P.; Ribot, E.M.; Garrett, N.; Alpern, J.A.; Akyildiz, A.; Theiss, A.L.; Nusrat, A.; Klapproth, J.M. Invasive Escherichia coli are a feature of Crohn's disease. Lab. Investig. 2007, 87, 1042-1054. [CrossRef] [PubMed]

58. Rolhion, N.; Darfeuille-Michaud, A. Adherent-invasive Escherichia coli in inflammatory bowel disease. Inflamm. Bowel Dis. 2007, 13, 1277-1283. [CrossRef] [PubMed]

59. Martinez-Medina, M.; Aldeguer, X.; Lopez-Siles, M.; González-Huix, F.; López-Oliu, C.; Dahbi, G.; Blanco, J.E.; Blanco, J.; Garcia-Gil, L.J.; Darfeuille-Michaud, A. Molecular diversity of Escherichia coli in the human gut: New ecological evidence supporting the role of adherent-invasive E. coli (AIEC) in Crohn's disease. Inflamm. Bowel Dis. 2009, 15, 872-878. [CrossRef] [PubMed] 